\title{
Chronic Hyperosmolality Increases NHE3 Activity In OKP Cells
}

Patrice Ambühl, ${ }^{*}$ Morimasa Amemiya, ${ }^{*}$ Patricia A. Preisig, ${ }^{\star}$ Orson W. Moe, ${ }^{\ddagger}$ and Robert J. Alpern*

*Department of Internal Medicine, The University of Texas Southwestern Medical Center, Dallas, Texas $75235-8856$; and the ${ }^{\ddagger}$ Dallas

Veterans Affairs Medical Center, Dallas, Texas 75216

\begin{abstract}
This study investigated the effect of chronic hypertonicity on the OKP cell $\mathrm{Na} / \mathrm{H}$ antiporter, encoded by $\mathrm{Na} / \mathrm{H}$ exchanger 3 (NHE3). Chronic (48 h) increases in extracellular glucose, mannitol, or raffinose concentration caused a significant increase in $\mathrm{Na} / \mathrm{H}$ antiporter activity, while increases in urea concentration were without effect. This effect was seen with changes in osmolality of only $20 \mathrm{mOsm} / \mathrm{liter}$, a magnitude that is observed clinically in poorly controlled diabetes mellitus. Increases in mannitol concentration acutely inhibited and chronically stimulated $\mathrm{Na} / \mathrm{H}$ antiporter activity. The increase in $\mathrm{Na} / \mathrm{H}$ antiporter activity induced by hypertonic incubation was resistant to $10^{-7}$ and $5 \times 10^{-6} \mathrm{M}$ but inhibited by $10^{-4} \mathrm{M}$ ethylisopropyl amiloride, consistent with regulation of NHE3. In addition, hypertonicity increased total cellular and plasma membrane NHE3 protein abundance twofold, with only a small increase in NHE3 mRNA abundance. We conclude that chronic pathophysiologically relevant increases in tonicity lead to increases in NHE3 protein abundance and activity. This may be responsible for increased proximal tubule apical membrane $\mathrm{Na} / \mathrm{H}$ antiporter activity in poorly controlled diabetes mellitus, which could then contribute to hypertension, glomerular hyperfiltration and diabetic nephropathy. (J. Clin. Invest. 1998. 101:170-177.) Key words: $\mathrm{Na} / \mathrm{H}$ antiporter • diabetes mellitus $\bullet$ hyperglycemia $\bullet$ hypertension $\bullet$ hypertonicity
\end{abstract}

\section{Introduction}

The proximal tubule is responsible for the majority of $\mathrm{NaCl}$ reabsorption in the kidney, and thus is important in the regulation of extracellular fluid volume and blood pressure. $\mathrm{NaCl}$ absorption in this segment is mediated by an $\mathrm{Na} / \mathrm{H}$ antiporter functioning in parallel with a $\mathrm{Cl} /$ base exchanger $(1,2)$. A number of physiologic regulators of $\mathrm{NaCl}$ absorption, such as angiotensin II, endothelin, dopamine, and adrenergic catecholamines have been demonstrated to regulate $\mathrm{NaCl}$ absorption through regulation of the apical membrane $\mathrm{Na} / \mathrm{H}$ antiporter (3). While five mammalian $\mathrm{Na} / \mathrm{H}$ antiporter gene isoforms have been cloned (4-9), present evidence suggests that a major

Patrice Ambühl and Morimasa Amemiya contributed equally to the studies reported in this paper.

Address correspondence to Robert J. Alpern, M.D., Nephrology Division, UT Southwestern, 5323 Harry Hines Blvd., Dallas, TX 75235-8856. Phone: 214-648-2754; FAX: 214-648-2071; E-mail: ralper@mednet.swmed.edu

Received for publication 13 March 1997 and accepted in revised form 29 October 1997.

J. Clin. Invest.

(C) The American Society for Clinical Investigation, Inc. 0021-9738/98/01/0170/08 \$2.00

Volume 101, Number 1, January 1998, 170-177

http://www.jci.org fraction of apical membrane $\mathrm{Na} / \mathrm{H}$ exchange mediating transepithelial transport is encoded by $\mathrm{Na} / \mathrm{H}$ exchanger 3 (NHE3) ${ }^{1}$ $(10,11)$. OKP cells express an apical membrane $\mathrm{Na} / \mathrm{H}$ antiporter that is encoded by NHE3 and is regulated in a similar fashion to that of the proximal tubule apical membrane $\mathrm{Na} / \mathrm{H}$ antiporter (12).

Diabetes mellitus is associated with hypertension and renal disease. In rats, induction of diabetes mellitus causes an increase in renal brush border membrane $\mathrm{Na} / \mathrm{H}$ antiporter activity (13). Increased activity was dependent on the control of the diabetes in that insulin therapy reversed the effect. In this study, we examined the effect of chronic increases in media glucose concentration on $\mathrm{Na} / \mathrm{H}$ antiporter activity in OKP cells. The results demonstrate that exposure of OKP cells to pathophysiologically relevant increases in glucose concentration for $48 \mathrm{~h}$, causes an increase in $\mathrm{Na} / \mathrm{H}$ antiporter activity that persists after the cells are removed from the hyperglycemic media. This effect is shown to be due to cell shrinkage in that it is elicited by increases in mannitol or raffinose concentration, but is not elicited by increases in urea concentration. The increase in $\mathrm{Na} / \mathrm{H}$ antiporter activity is associated with an increase in NHE3 protein abundance.

\section{Methods}

Materials and supplies. All chemicals were obtained from Sigma Chemical Co. (St. Louis, MO) unless otherwise noted as follows: penicillin and streptomycin from Whittaker M.A. Bioproducts, Inc. (Walkersville, MD); acetoxymethyl derivative of 2'7'-bis(2-carboxyethyl)-5-(and-6)-carboxyfluorescein (BCECF), and ethylisopropyl amiloride (EIPA) from Molecular Probes, Inc. (Eugene, OR); culture media from GIBCO BRL (Gaithersburg, MD); and enhanced chemiluminescence kit from Amersham Corp. (Arlington Heights, IL).

Cell culture. OKP cells, a gift from K. Hruska (Washington University, St. Louis, MO), are a clonal line of the opossum kidney (OK) cell line, originally described by Cole et al. (14). OKP cells were passaged in DME (100 mg/dl, $5.55 \mathrm{mM}$ glucose) supplemented with $100 \mathrm{U} / \mathrm{ml}$ penicillin, $100 \mu \mathrm{g} / \mathrm{ml}$ streptomycin, and $10 \%$ fetal bovine serum (FBS). For experimentation, OKP cells were grown to confluence and rendered quiescent by serum deprivation for $24 \mathrm{~h}$ before study. Cells were then maintained in serum-free media with additives as indicated for 1-48 h, and then studied. In all studies, control and experimental cells were from the same passage and were assayed on the same day.

Measurement of intracellular $\mathrm{pH}$ and $\mathrm{Na} / \mathrm{H}$ antiporter activity. Continuous measurement of cytoplasmic $\mathrm{pH}\left(\mathrm{pH}_{\mathrm{i}}\right)$ was accomplished using the intracellularly trapped $\mathrm{pH}$-sensitive dye, $\mathrm{BCECF}$, as previously described (15). Cells were loaded with $10 \mu \mathrm{M}$ acetoxymethyl ester of $\mathrm{BCECF}$ for $35 \mathrm{~min}$ at $37^{\circ} \mathrm{C}$, and $\mathrm{pH}_{\mathrm{i}}$ estimated from the ratio of fluorescence with excitation at wavelengths of 500 and $450 \mathrm{~nm}$, with $530 \mathrm{~nm}$ emission in a computer-controlled spectrofluorometer (8000C; SLM Instruments, Inc., Urbana, IL). The BCECF excitation fluorescence ratio was calibrated intracellularly using the K/nigericin approach as described (16).

1. Abbreviations used in this paper: $\mathrm{BCECF}, 2^{\prime} 7^{\prime}$-bis(2-carboxyethyl)5-(and-6)-carboxyfluorescein; EIPA, ethylisopropyl amiloride; MAP, mitogen activated protein; $\mathrm{NHE} 3, \mathrm{Na} / \mathrm{H}$ exchanger 3; OK, opossum kidney. 
$\mathrm{Na} / \mathrm{H}$ antiporter activity was assayed as the initial rate of $\mathrm{Na}-$ dependent $\mathrm{pH}_{\mathrm{i}}$ increase after an acid load in the absence of $\mathrm{CO}_{2} /$ $\mathrm{HCO}_{3}$, as previously described (15). Cells were acidified with $13 \mu \mathrm{M}$ nigericin in Na-free solution. The initial rate of $\mathrm{pH}_{\mathrm{i}}$ increase $\left(\mathrm{dpH}_{\mathrm{i}} / \mathrm{dt}\right)$ upon $\mathrm{Na}$ addition was calculated by drawing a tangent to the initial deflection. To calculate buffer capacity, cells were pulsed with $10 \mathrm{mM}$ ammonium chloride in the Na-free perfusate at the trough $\mathrm{pH}_{\mathrm{i}}$, as described (15). Incubation in hypertonic glucose or mannitol for $48 \mathrm{~h} \mathrm{had}$ no effect on buffer capacity. Results are therefore reported as $\mathrm{dpH}_{\mathrm{i}} / \mathrm{dt}$.

Immunoblot. Cells were rinsed with ice cold PBS three times and dounce homogenized in isotonic Tris-buffered saline (in $\mathrm{mM}$ : $\mathrm{NaCl}, 150$; Tris- $\mathrm{HCl}, 50$; $\mathrm{pH}$ 7.5, EDTA, 5) containing proteinase inhibitors (in $\mu \mathrm{g} / \mathrm{ml}$ : PMSF, 100; Aprotinin, 4; Leupeptin, 4). Nuclei were removed by centrifugation at $13,000 \mathrm{~g}$ at $4^{\circ} \mathrm{C}$. Membranes were pelleted by centrifugation at $100,000 \mathrm{~g}$ for $20 \mathrm{~min}$. The resulting pellet was resuspended in Tris-buffered saline and total protein content determined by the method of Bradford. $15 \mu \mathrm{g}$ of protein were diluted 1:5 in $5 \times$ SDS loading buffer ( $1 \mathrm{mM}$ Tris $\mathrm{HCl}, \mathrm{pH}$ 6.8, $1 \%$ SDS, $10 \%$ glycerol, $1 \% 2$ mercaptoethanol), size fractionated by SDS PAGE ( $7.5 \%$ gel), and electrophoretically transferred to nitrocellulose. After blocking with $5 \%$ nonfat milk and $0.05 \%$ Tween 20 in PBS for $1 \mathrm{~h}$, blots were probed in the same buffer for $1 \mathrm{~h}$ with a polyclonal antiopossum NHE3 antibody (antiserum 5683, generated against a maltose binding protein/NHE3 [aa 484-839] fusion protein) at a dilution of $1: 300$. Blots were washed in $0.05 \%$ Tween 20 in PBS one time for $15 \mathrm{~min}$ and two times for $5 \mathrm{~min}$, incubated with a 1:10,000 dilution of peroxidase-labeled sheep anti-rabbit IgG in 5\% nonfat milk and $0.05 \%$ Tween 20 in PBS for $1 \mathrm{~h}$, washed as above, and then visualized by enhanced chemiluminescence. NHE3 protein abundance was quantitated by densitometry (Molecular Dynamics ImageQuant Software version 3.3; Molecular Dynamics, Sunnyvale, CA). This procedure labeled a $90-\mathrm{kD}$ band that was not seen when antibody was preincubated with fusion protein or when preimmune serum replaced the anti-NHE3 antiserum.

To measure plasma membrane NHE3, we used surface biotinylation, as described (17-19). Monolayers were placed on ice and washed with ice-cold PBS with $0.1 \mathrm{mM} \mathrm{CaCl}_{2}$ and $1.0 \mathrm{mM} \mathrm{MgCl} 2$ twice. The apical surface was then exposed to $1.5 \mathrm{mg} / \mathrm{dl}$ sulfoNHS-SSbiotin (Pierce Chemical Co., Rockford, IL) in $10 \mathrm{mM}$ triethanolamine ( $\mathrm{pH} 7.5$ ), $2 \mathrm{mM} \mathrm{CaCl}_{2}$, and $150 \mathrm{mM} \mathrm{NaCl}$ for $1 \mathrm{~h}$ at $4^{\circ} \mathrm{C}$. After labeling, filters were washed four times with quenching solution (PBS containing $1 \mathrm{mM} \mathrm{MgCl}_{2}, 0.1 \mathrm{mM} \mathrm{CaCl}_{2}$, and $100 \mathrm{mM}$ glycine) for $20 \mathrm{~min}$ at $4^{\circ} \mathrm{C}$. Cells were then extracted with RIPA buffer $(150 \mathrm{mM} \mathrm{NaCl}, 50$ $\mathrm{mM}$ Tris ( $\mathrm{pH} 7.4$ ), $50 \mathrm{mM} \beta$-glycerophosphate, $50 \mathrm{mM} \mathrm{NaF}, 1 \mathrm{mM} \mathrm{Na}$ orthovanadate, $2.5 \mathrm{mM}$ EDTA, $5 \mathrm{mM}$ EGTA, $0.5 \mathrm{mM}$ dithiothreitol, $1 \%$ Triton X-100, $0.5 \%$ Na deoxycholate, $0.1 \%$ SDS, $100 \mu \mathrm{g} / \mathrm{ml} \mathrm{PMSF}$, $5 \mu \mathrm{g} / \mathrm{ml}$ aprotinin, $5 \mu \mathrm{g} / \mathrm{ml}$ leupeptin, $2 \mu \mathrm{g} / \mathrm{ml}$ pepstatin), samples precipitated with streptavidin-coupled agarose, and the precipitate subjected to SDS-PAGE and blotting with anti-NHE3 antibodies.

RNA blotting. RNA was extracted using RNeasy (QIAGEN, Inc., Chatsworth, CA). $15 \mu \mathrm{g}$ of total RNA was size fractionated by agarose-formaldehyde gel electrophoresis and transferred to nylon membranes. The radiolabeled NHE3 probe was synthesized from a full-length OKP NHE3 cDNA (12) by the random hexamer method, and the $18 \mathrm{~S}$ probe was an end-labeled oligonucleotide. Prehybridization, hybridization, and washing were done as previously described (20). Filters were exposed to film overnight at $-70^{\circ} \mathrm{C}$ and labeling quantitated by densitometry. Changes in NHE3 abundance were normalized for changes in 18S rRNA abundance.

Statistics. Data are reported as mean \pm SEM. Statistical significance was assessed using an unpaired Student's $t$ test or analysis of variance (ANOVA) as appropriate.

\section{Results}

Chronic increases in [glucose] increase $\mathrm{Na} / \mathrm{H}$ antiporter activity. To determine the effect of chronic exposure to increased
Figure 1. Increases in media glucose concentration increase $\mathrm{Na} / \mathrm{H}$ antiporter activity. Cells were preincubated in media glucose concentrations of 100 or 460 $\mathrm{mg} / \mathrm{dl}$ for $48 \mathrm{~h} . \mathrm{Na} / \mathrm{H}$ antiporter activity was then assayed and is plotted as $\mathrm{dpH}_{\mathrm{i}} / \mathrm{dt}(\mathrm{pH}$ $\mathrm{U} / \mathrm{min}) . n=4 ; * P<$ 0.01 versus control.

glucose concentration, quiescent OKP cells were preincubated in low glucose DME $(100 \mathrm{mg} / \mathrm{dl}$ glucose $)$ or in a similar medium with [glucose] raised to $460 \mathrm{mg} / \mathrm{dl}$ ( $\Delta$ osmolality $=20$ $\mathrm{mOsm} / \mathrm{liter}$ ) for $48 \mathrm{~h}$. After this preincubation, cells were incubated in isoosmotic media (low glucose DME) for $45 \mathrm{~min}$ and $\mathrm{Na} / \mathrm{H}$ antiporter activity assayed. As shown in Fig. 1, cells preincubated in media with a high glucose concentration demonstrated a 39\% increase in $\mathrm{Na} / \mathrm{H}$ antiporter activity. Fig. 2 shows a dose-response curve, plotting $\mathrm{Na} / \mathrm{H}$ antiporter activity as a function of preincubation glucose concentration. Progressive increases in media glucose concentration led to progressive increases in $\mathrm{Na} / \mathrm{H}$ antiporter activity, which achieved a maximal effect at a glucose concentration $360 \mathrm{mg} / \mathrm{dl}$ above that of control media.

Chronic increases in extracellular fluid tonicity increase $\mathrm{Na} / \mathrm{H}$ antiporter activity. This effect of glucose could be due to a specific effect of glucose or to an increase in extracellular fluid osmolality. To differentiate between these possibilities, we compared the effects of $48 \mathrm{~h}$ preincubation in media made hyperosmolar by addition of $20 \mathrm{mM}$ glucose or mannitol. As can be seen in Fig. 3, the effects of glucose and mannitol were similar. Cells preincubated in high glucose demonstrated a $63 \%$ increase and cells preincubated in mannitol exhibited a $57 \%$ increase in $\mathrm{Na} / \mathrm{H}$ antiporter activity. In that mannitol is not metabolized and does not enter cells, these results suggest

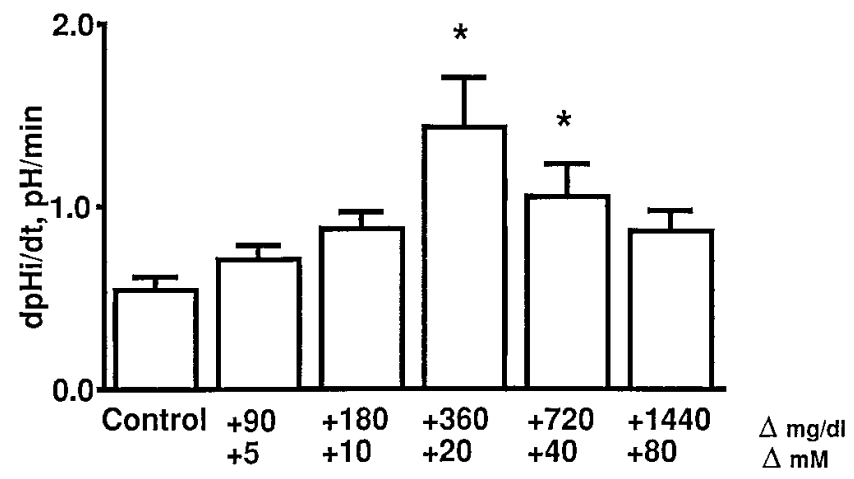

Figure 2. Increases in media glucose concentration activate the $\mathrm{Na} / \mathrm{H}$ antiporter: dose dependence. Control cells were preincubated in a media glucose concentration of $100 \mathrm{mg} / \mathrm{dl}$, while experimental cells were preincubated in increasing glucose concentrations for $48 \mathrm{~h} . \mathrm{Na} / \mathrm{H}$ antiporter activity is plotted as a function of the increase in glucose concentration in $\mathrm{mg} / \mathrm{dl}$ and in $\mathrm{mM}$. Control, $n=12 ;+5 \mathrm{mM}, n=13$; $+10 \mathrm{mM}, n=11$; +20 mM, $n=12$; +40 mM, $n=10$; +80 mM, $n=$ 11. $* P<0.05$ versus control. 


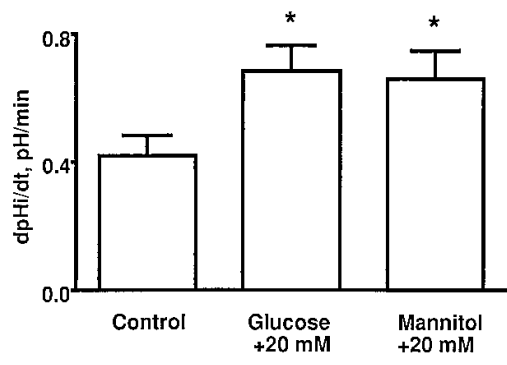

Figure 3. Increases in extracellular fluid osmolality increase $\mathrm{Na} / \mathrm{H}$ antiporter activity. Media osmolality was increased by addition of $20 \mathrm{mM}$ glucose or mannitol for $48 \mathrm{~h}$. $\mathrm{Na} / \mathrm{H}$ antiporter activity is plotted. Control, $n=17$ glucose, $n=22$; mannitol, $n=20 . * P<0.05$ versus control.

that the effect of glucose is due to an increase in extracellular osmolality.

Fig. 4 shows a dose-response curve for the mannitol effect. Unlike the response to glucose, increases in osmolality above $20 \mathrm{mOsm} /$ liter led to further increases in $\mathrm{Na} / \mathrm{H}$ antiporter activity. These results suggest that chronic increases in extracellular fluid osmolality lead to progressive increases in $\mathrm{Na} / \mathrm{H}$ antiporter activity. Very high concentrations of glucose may have a toxic effect, or glucose uptake at high concentrations may dissipate the osmotic gradient.

To further address the solute specificity of the effect, we compared $48 \mathrm{~h}$ preincubation in media made hyperosmolar by addition of $80 \mathrm{mM}$ mannitol, raffinose, or urea. As seen in Fig. 5 , mannitol and raffinose, two solutes that cannot enter cells, both caused similar adaptive increases in $\mathrm{Na} / \mathrm{H}$ antiporter activity ( $98 \%$ and $86 \%$ increase, respectively). However, urea, which enters cells more freely, did not elicit an increase in $\mathrm{Na} / \mathrm{H}$ antiporter activity. Similarly, preincubation in media made hypertonic by addition of $20 \mathrm{mM}$ urea had no effect on $\mathrm{Na} / \mathrm{H}$ antiporter activity (data not shown). These results suggest that cell shrinkage is responsible for the increase in $\mathrm{Na} / \mathrm{H}$ antiporter activity.

In the studies presented thus far, cells preincubated in high extracellular fluid osmolality for $48 \mathrm{~h}$ were exposed to isotonic solutions for $45 \mathrm{~min}$ before assay. This was done to eliminate

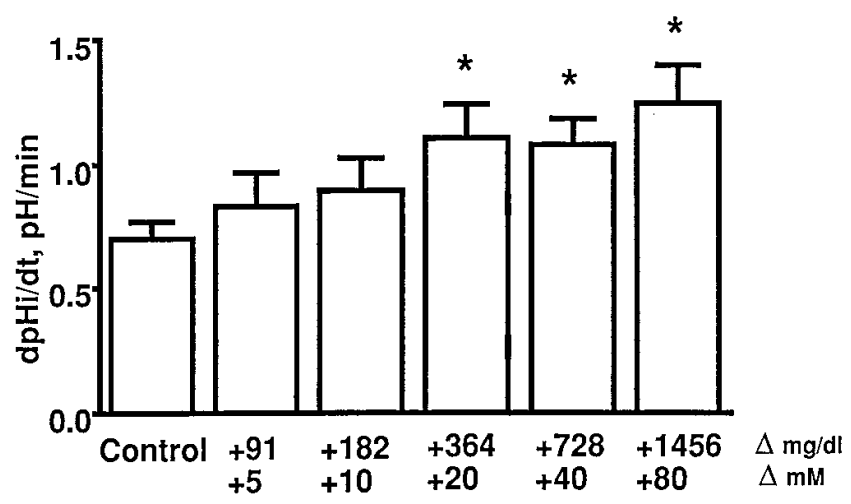

Figure 4. Mannitol increases $\mathrm{Na} / \mathrm{H}$ antiporter activity: dose dependence. Cells were preincubated in control media or in media where osmolality was increased by mannitol addition for $48 \mathrm{~h} . \mathrm{Na} / \mathrm{H}$ antiporter activity is plotted as a function of the amount of mannitol added, expressed as $\mathrm{mg} / \mathrm{dl}$ or $\mathrm{mM}$. Control, $n=8 ;+5 \mathrm{mM}, n=9 ;+10$ $\mathrm{mM}, n=9 ;+20 \mathrm{mM}, n=9 ;+40 \mathrm{mM}, n=9 ;+80 \mathrm{mM}, n=9$. *P< 0.05 versus control.

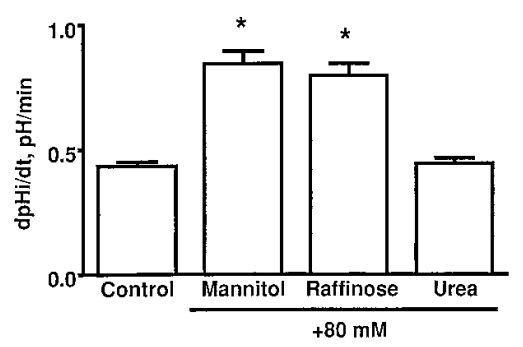

Figure 5. Hypertonicity increases $\mathrm{Na} / \mathrm{H}$ antiporter activity. Medium osmolality was increased by addition of $80 \mathrm{mM}$ mannitol, raffinose, or urea for $48 \mathrm{~h}$. $\mathrm{Na} / \mathrm{H}$ antiporter activity is plotted. Control, $n=7$; mannitol, $n=8$; raffinose, $n=4$; urea, $n=7 . * P<0.001$.

any effects of hypertonicity during the assay, but may have led to acute cell swelling, which could possibly be responsible for the increased $\mathrm{Na} / \mathrm{H}$ antiporter activity. To examine this, we performed studies wherein after $48 \mathrm{~h}$ preincubation in solutions of high osmolality, cells were then exposed to similar hyperosmolar solutions during assay of the $\mathrm{Na} / \mathrm{H}$ antiporter. In Fig. $6 \mathrm{~A}$, osmolality was increased by addition of $20 \mathrm{mM}$ mannitol, while in Fig. $6 B$, osmolality was increased by addition of $80 \mathrm{mM}$ mannitol. The first bar represents control cells, the second bar represents cells preincubated in hypertonic media for $48 \mathrm{~h}$ and then assayed in isotonic media, and the last bar represents cells preincubated and assayed in hypertonic media. In all cases preincubation in hypertonic media increased $\mathrm{Na} / \mathrm{H}$ antiporter activity. Thus, when cell swelling before assay was prevented, $\mathrm{Na} / \mathrm{H}$ antiporter activity was still increased by chronic hypertonic incubation.

Fig. 7 shows a complete time course wherein cells were preincubated and assayed in hypertonic solution. At $1 \mathrm{~h}$, hypertonicity resulted in inhibition of $\mathrm{Na} / \mathrm{H}$ antiporter activity, as previously reported (21-23). From 6 to $24 \mathrm{~h}$, net inhibition disappeared and there was a tendency to increase $\mathrm{Na} / \mathrm{H}$ antiporter activity. This became significant at $48 \mathrm{~h}$. This gradual transition from net inhibition to net stimulation likely represents a loss of the acute inhibitory effect which is not present at $48 \mathrm{~h}$ (Fig. 6), and an increase in the chronic stimulatory effect. Given this time course, it is possible that the magnitude of stimulation would increase further with greater duration of hypertonic incubation.

Hypertonicity activates NHE3. To prevent any effects of acute cell swelling, the remaining studies were performed with $48 \mathrm{~h}$ hypertonic preincubation followed by assay in hypertonic media. First, we addressed whether chronic hypertonic incubation increased the activity of an EIPA-resistant $\mathrm{Na} / \mathrm{H}$ antiporter. Previously, we have shown that OKP cells express an $\mathrm{Na} / \mathrm{H}$ antiporter whose $\mathrm{IC}_{50}$ for EIPA is $4.5 \mu \mathrm{M}$ when assayed with $15 \mathrm{mM} \mathrm{Na}(20)$. This kinetic behavior is consistent with that of NHE3, and agrees with the finding that OKP cells express NHE3 mRNA (12). Nevertheless, it is possible that the increase in $\mathrm{Na} / \mathrm{H}$ antiporter activity induced by chronic hypertonicity is mediated by a different isoform. To test this, kinetics for EIPA inhibition were performed on cells preincubated in control or hypertonic media for $48 \mathrm{~h}$. For these studies, $\mathrm{Na} / \mathrm{H}$ antiporter activity was measured with $15 \mathrm{mM} \mathrm{Na}$. In this setting, $10^{-7}$ and $5 \times 10^{-6} \mathrm{M}$ EIPA would be predicted to completely inhibit NHE1 and other EIPA-sensitive isoforms, while having no effect on NHE3. $10^{-4} \mathrm{M}$ EIPA should inhibit all $\mathrm{Na} / \mathrm{H}$ antiporter isoforms. As shown in Fig. $8,10^{-7}$ and $5 \times$ $10^{-6} \mathrm{M}$ EIPA had no significant effect on $\mathrm{Na} / \mathrm{H}$ antiporter ac- 

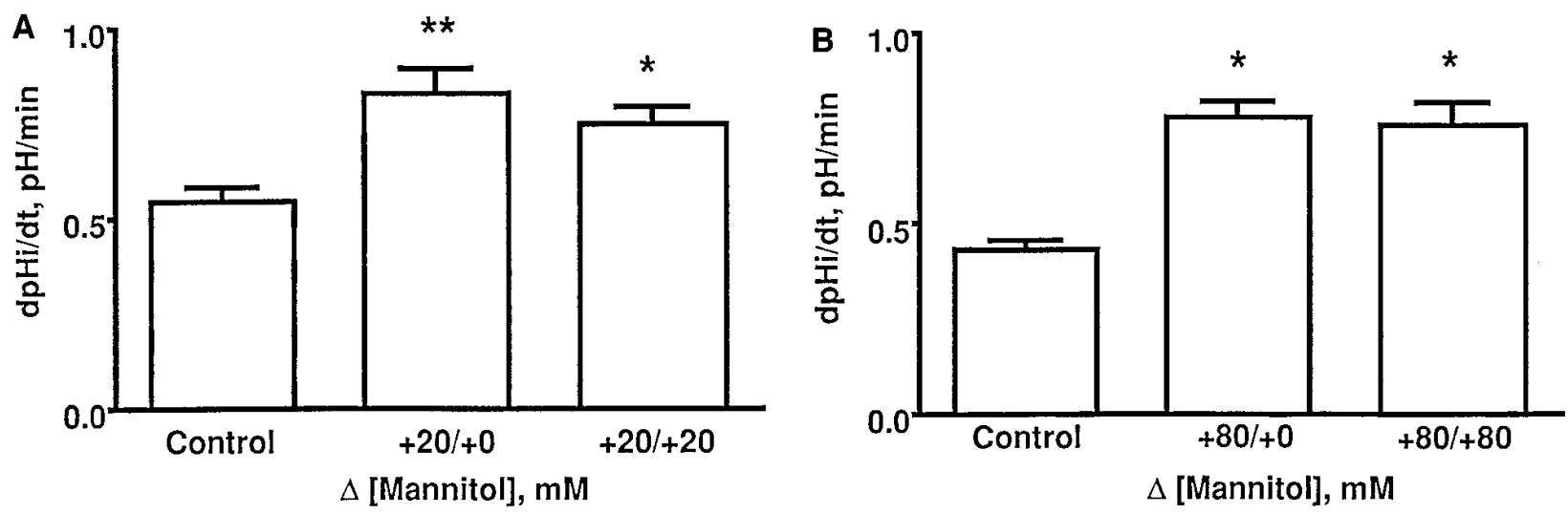

Figure 6. Chronic hypertonicity increases $\mathrm{Na} / \mathrm{H}$ antiporter activity: effect of tonicity during assay. Cells were preincubated in control media and assayed in control media (Control), preincubated in hypertonic media and assayed in control media $(+20 /+0$ or $+80 /+0)$ or preincubated in hypertonic media and assayed in hypertonic media $(+20 /+20$ or $+80 /+80)$. Preincubation was for $48 \mathrm{~h}$, and assay was $45 \mathrm{~min}$ in duration. $\mathrm{Na} / \mathrm{H}$ antiporter activity is plotted. ( $A$ ) Osmolality was increased by $20 \mathrm{mOsm} /$ liter. Control, $n=4 ;+20 /+0, n=4 ;+20 /+20, n=5$. * $P<0.05 ; * * P<$ 0.01 versus control. $(B)$ Osmolality was increased by $80 \mathrm{mOsm} / \mathrm{liter}$. Control, $n=4 ;+80 /+0, n=5 ;+80 /+80, n=5$. * $P<0.001$ versus control.

tivity measured under basal conditions or after hypertonic preincubation, and had no effect on the hypertonicity-induced increase in antiporter activity. On the other hand, $10^{-4} \mathrm{M}$ EIPA completely inhibited all of these parameters. Thus, these studies demonstrate that chronic hypertonic incubation increases the activity of an EIPA-resistant $\mathrm{Na} / \mathrm{H}$ antiporter, likely NHE3.

An increase in NHE3 activity could be related to an increase in NHE3 protein abundance. To examine this, Western blots were performed with anti-NHE3 antiserum. Fig. 9 shows results of preincubating OKP cells in media made hypertonic by addition of mannitol. Preincubation in $80 \mathrm{mM}$ mannitol for $48 \mathrm{~h}$ caused a $131 \pm 18 \%$ increase in NHE3 protein abundance, while preincubation in $20 \mathrm{mM}$ mannitol for $48 \mathrm{~h}$ caused a $48 \pm 5 \%$ increase in NHE3 protein abundance (Fig. $9 A$ ). At 24 h, $20 \mathrm{mM}$ mannitol caused a $132 \pm 21 \%$ increase and $80 \mathrm{mM}$ mannitol caused a $115 \pm 30 \%$ increase in NHE3 abundance (Fig. $9 B$ ).

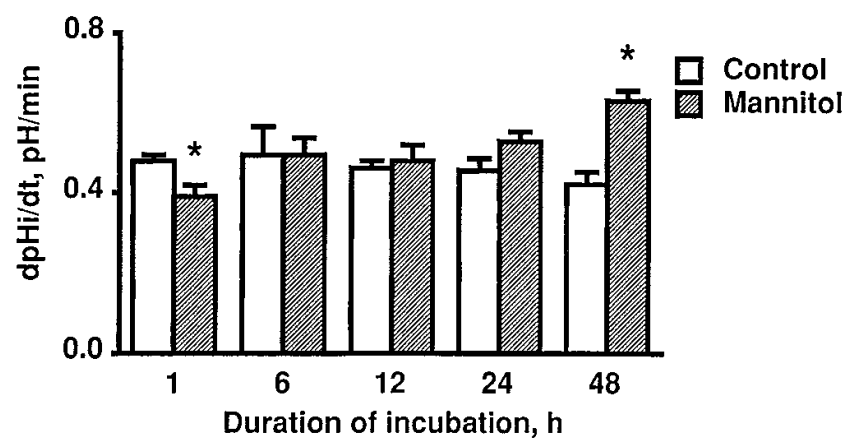

Figure 7. Hypertonicity increases $\mathrm{Na} / \mathrm{H}$ antiporter activity: time course. Cells preincubated in media made hypertonic by addition of $80 \mathrm{mM}$ mannitol were compared with control cells. Cells were preincubated and assayed under isotonic (Control) or hypertonic (Manni$t o l)$ conditions. $\mathrm{Na} / \mathrm{H}$ antiporter activity is plotted. Control: $1 \mathrm{~h}, n=5$; $6 \mathrm{~h}, n=4 ; 12 \mathrm{~h}, n=4 ; 24 \mathrm{~h}, n=5 ; 48 \mathrm{~h}, n=4$. Mannitol: $1 \mathrm{~h}, n=4$; $6 \mathrm{~h}, n=4 ; 12 \mathrm{~h}, n=4 ; 24 \mathrm{~h}, n=5 ; 48 \mathrm{~h}, n=4 .{ }^{*} P<0.05$ versus control.
The observation that hypertonicity caused an increase in NHE3 protein abundance but no increase in activity at $24 \mathrm{~h}$ was surprising. Therefore, we used membrane biotinylation to measure plasma membrane NHE3 abundance at 24 and $48 \mathrm{~h}$. Results are shown in Fig. 10. Hypertonicity caused a $135 \pm 59 \%$ increase in plasma membrane NHE3 at $48 \mathrm{~h}(P<0.02)$. However, hypertonicity did not affect plasma membrane abundance at $24 \mathrm{~h}(-38 \pm 20 \%$, ns $)$. Thus, at $24 \mathrm{~h}$ there is an increase in NHE3 protein abundance but no change in activity because the transporter has not trafficked to the plasma membrane. At $48 \mathrm{~h}$ NHE3 moves to the plasma membrane and results in increased activity.

Increases in media urea concentration were without effect on $\mathrm{Na} / \mathrm{H}$ antiporter activity (Fig. 5). Preincubation in $80 \mathrm{mM}$ urea also did not affect NHE3 protein abundance $(\Delta$ NHE3 abundance $=-19 \pm 12 \%$; Fig. 11$)$.

An increase in NHE3 protein abundance can be due to an increase in NHE3 mRNA abundance, or can be due to direct effects on protein synthesis or degradation. Next, we examined whether chronic preincubation in hypertonic media caused an increase in NHE3 mRNA abundance. Preincubating OKP cells in media made hypertonic by addition of $80 \mathrm{mM}$ mannitol caused a $38 \pm 14 \%$ increase at $24 \mathrm{~h}$ and a $36 \pm 13 \%$ increase at $48 \mathrm{~h}$ in NHE3 mRNA abundance normalized for 18S rRNA abundance (Fig. 12). Similar results were obtained if glyceraldehyde-3-phosphate dehydrogenase (GAPDH) was used for normalization. While this effect was consistent, it was small and its physiologic significance is uncertain. The approximately twofold increases in NHE3 protein abundance and activity induced by hypertonicity seem to be too large to be accounted for by the small $35-40 \%$ change in NHE3 mRNA abundance.

To examine whether the effect of hypertonic preincubation requires protein synthesis, studies were performed with cycloheximide. $100 \mu \mathrm{M}$ cycloheximide was added to cells $1 \mathrm{~h}$ before control or experimental preincubation. This concentration of cycloheximide inhibits $94 \%$ of $\left[{ }^{3} \mathrm{H}\right]$ leucine incorporation in OKP cells (15). In addition, this concentration of cycloheximide inhibited the chronic effects of cAMP and dexamethasone on $\mathrm{Na} / \mathrm{H}$ antiporter activity in OKP cells $(15,24)$. However, as 

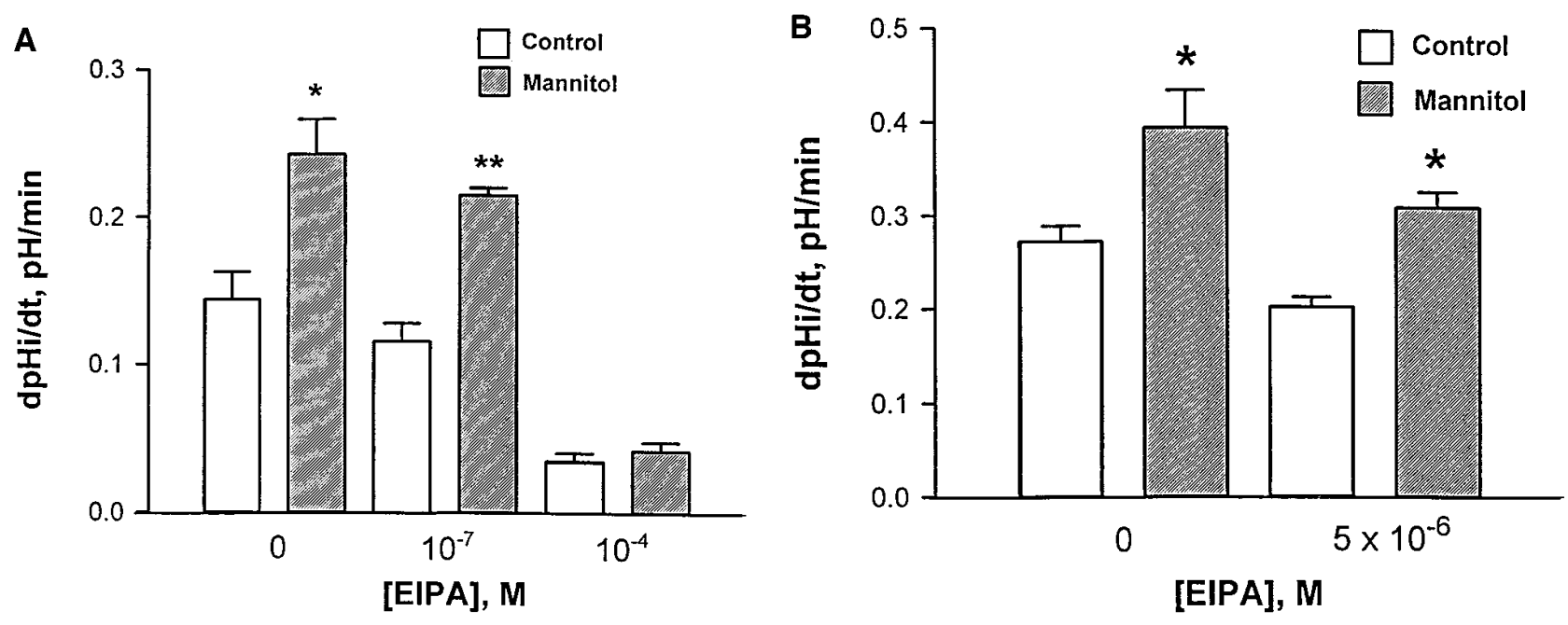

Figure 8. Chronic hyperosmolality increases the activity of an EIPA resistant $\mathrm{Na} / \mathrm{H}$ antiporter. Cells were preincubated in control media or media made hypertonic by addition of $80 \mathrm{mM}$ mannitol. Cells were preincubated and assayed under isotonic (Control) or hypertonic (Mannitol) conditions. Antiporter activity was assayed with $15 \mathrm{mM} \mathrm{Na}$, in the absence of EIPA, or in the presence of $10^{-7} \mathrm{M} \mathrm{EIPA}(A), 5 \times 10^{-6} \mathrm{M} \mathrm{EIPA}$ $(B)$, or $10^{-4} \mathrm{M}$ EIPA $(A) . \mathrm{Na} / \mathrm{H}$ antiporter activity is plotted. $n=4 . * P<0.05$ versus control; $* * P<0.001$ versus control.

shown in Fig. 13, the effect of hypertonic preincubation was seen even in the presence of cycloheximide. The significant decrease in basal activity induced by cycloheximide may be due to continued degradation of NHE3 protein in the absence of synthesis, and agrees with our previous results (15). Given the significant change in basal activities, it is difficult to compare the magnitudes of the stimulation in the presence and absence of cycloheximide. Nevertheless, it is clear that at least a component of the hypertonic effect occurs by mechanisms independent of protein synthesis.

\section{Discussion}

Diabetes mellitus is associated with renal $\mathrm{NaCl}$ retention and an expanded extracellular fluid volume. Volume expansion is responsible for hypertension and hyporeninemic hypoaldosteronism, and may contribute to the altered glomerular hemo- dynamics responsible for diabetic nephropathy. The incidence of diabetic nephropathy is increased by poor metabolic control and chronically high plasma glucose levels. An effect of hyperglycemia to increase proximal tubular NHE3 activity could explain all of these effects, and would thus be of significant clinical importance. In rats with diabetes mellitus, proximal tubule apical membrane $\mathrm{Na} / \mathrm{H}$ antiporter activity is increased (13). This effect was reversed by insulin treatment suggesting that hyperglycemia may be responsible. However, the increased $\mathrm{Na} / \mathrm{H}$ antiporter activity was also prevented by administration of $\mathrm{NaHCO}_{3}$, raising the possibility that ketoacidosis was responsible. In that $\mathrm{NaHCO}_{3}$ administration may inhibit $\mathrm{Na} / \mathrm{H}$ antiporter activity, it remains possible that hyperglycemia per se causes a chronic adaptive increase in $\mathrm{Na} / \mathrm{H}$ antiporter activity in the renal proximal tubule.

In OKP cells increases in media glucose concentration caused an increase in $\mathrm{Na} / \mathrm{H}$ antiporter activity over $48 \mathrm{~h}$, which
A
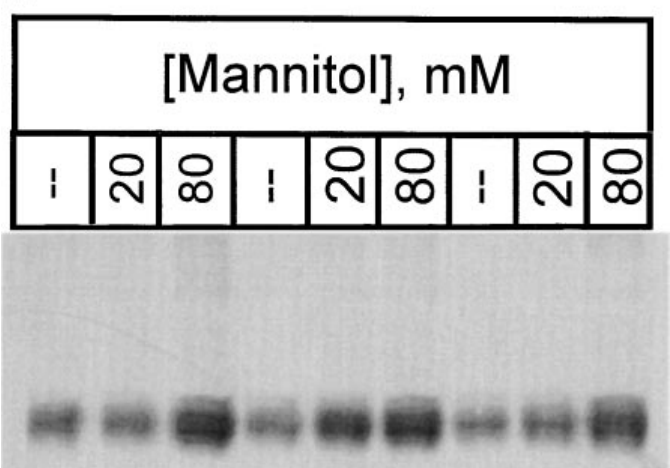

B
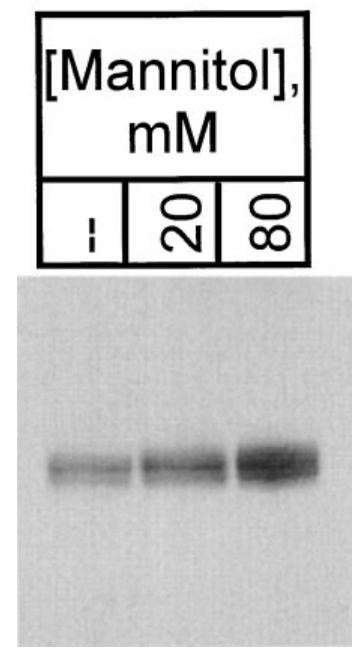

Figure 9. Mannitol increases NHE3 protein abundance. Cells were incubated in control media or media made hypertonic by addition of 20 or $80 \mathrm{mM}$ mannitol. Western blotting was then performed with anti-NHE3 antisera. (A) $48 \mathrm{~h}$ incubation. $(B) 24 \mathrm{~h}$ incubation. $n=8$. 


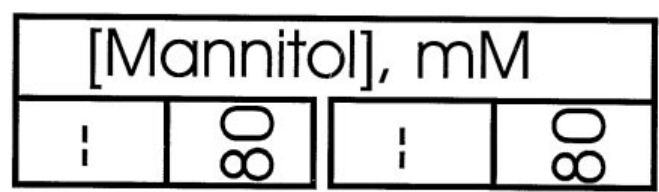

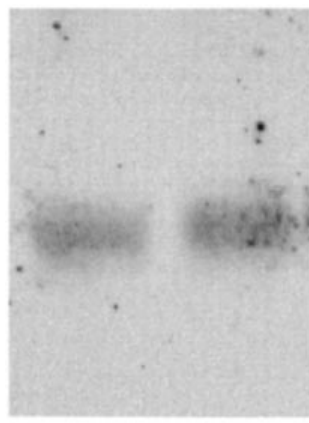

24 hours

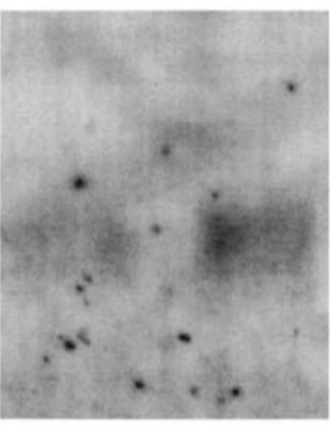

48 hours

\section{NHE3}

Figure 10. Plasma membrane NHE3 is increased by hypertonicity at $48 \mathrm{~h}$, but not at $24 \mathrm{~h}$. Cells were incubated in control media or media made hypertonic by addition $80 \mathrm{mM}$ mannitol. Plasma membrane proteins were then labeled with biotin and precipitated with agaroseconjugated streptavidin. Precipitates were blotted with anti-NHE3 antisera. (A) $48 \mathrm{~h}$ incubation. (B) $24 \mathrm{~h}$ incubation. $n=5$.

was significant with increases in glucose concentration of 360 $\mathrm{mg} / \mathrm{dl}$, corresponding to $20 \mathrm{mOsm} / \mathrm{liter}$. This increase in glucose concentration is pathophysiologically significant, in that it is seen in patients with poorly controlled diabetes mellitus. This effect was not unique to glucose, but was seen with increases in media osmolality elicited by addition of mannitol or raffinose. By contrast, increases in media osmolality elicited by

\begin{tabular}{|l|l|l|l|l|l|l|l|}
\hline \multicolumn{7}{|c|}{ [Urea], mM } \\
\hline i & $\infty$ & i & $\circ$ & i & $\circ$ & i & $\circ$ \\
\hline
\end{tabular}

Figure 11. Urea does not increase NHE3 protein abundance. Cells were incubated in control media or media made hypertonic by addition of $80 \mathrm{mM}$ urea $(n=4)$. Western blotting was then performed with antiNHE3 antisera.

addition of a more cell permeant solute, urea, had no effect on $\mathrm{Na} / \mathrm{H}$ antiporter activity, suggesting that this effect is mediated by cell shrinkage.

The increase in $\mathrm{Na} / \mathrm{H}$ antiporter activity induced by hypertonicity was EIPA-resistant, suggesting that it involved an increase in NHE3 activity. At $24 \mathrm{~h}$ there was an increase in NHE3 protein abundance but no increase in plasma membrane NHE3 or activity. At $48 \mathrm{~h}$ there were increases in total cellular NHE3, plasma membrane NHE3, and activity. While hypertonicity did induce a small increase in NHE3 mRNA abundance, this likely was not of sufficient magnitude to explain the increase in NHE3 protein abundance. The increase in protein abundance is most likely due to a direct effect of hypertonicity on NHE3 protein synthesis or degradation. In addition, studies with cycloheximide demonstrate that at least part of the response to hypertonicity can occur in the absence of protein synthesis.

\section{B}

A
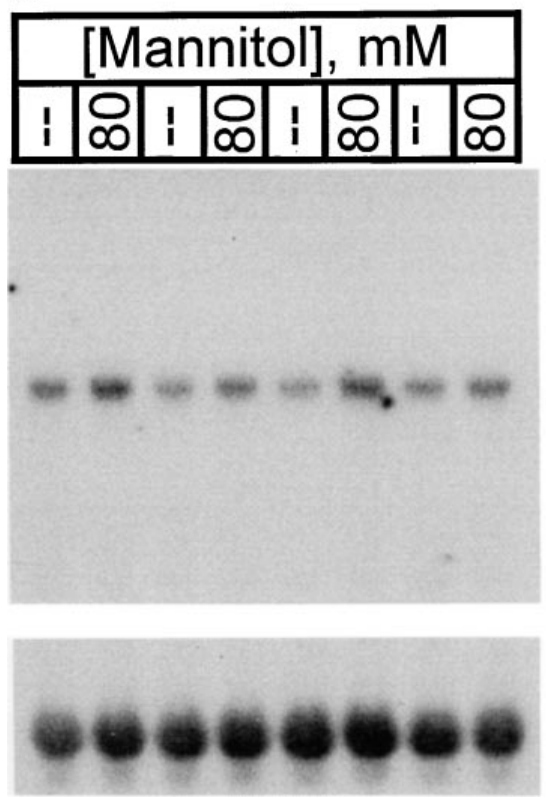
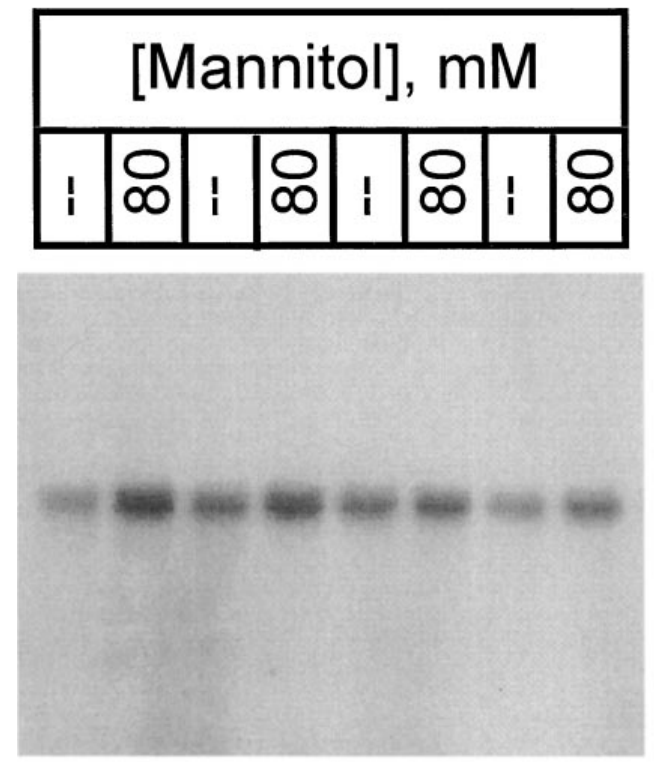

\section{NHE3}

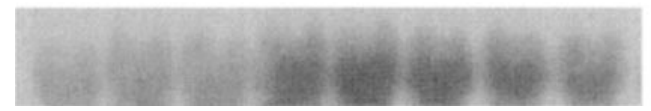

Figure 12. Mannitol increases NHE3 mRNA abundance. Cells were incubated in control media or media made hypertonic by addition of $80 \mathrm{mM}$ mannitol for $24(A, n=4)$ or $48 \mathrm{~h}(B, n=11)$. Blots were probed for NHE3 mRNA and 18S rRNA abundance. 


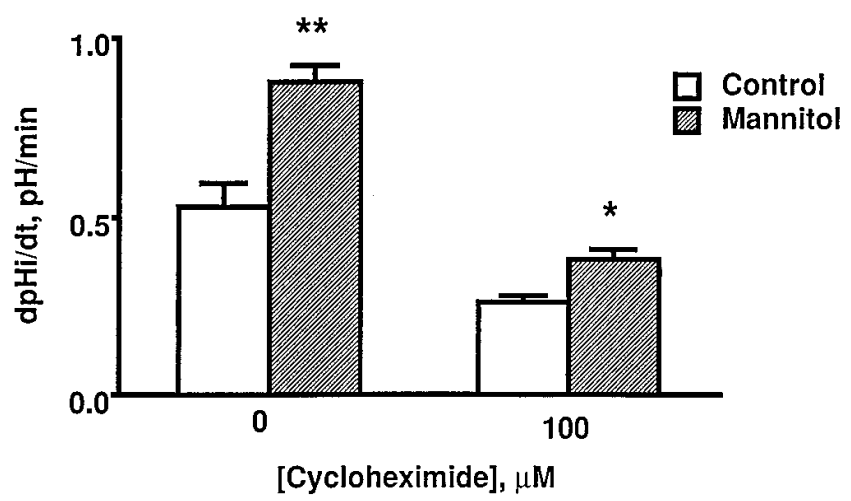

Figure 13. Increases in media osmolality increase $\mathrm{Na} / \mathrm{H}$ antiporter activity in the absence of protein synthesis. Cells were preincubated in control media or media made hypertonic by addition of $80 \mathrm{mM}$ mannitol. Cycloheximide was absent or present at $100 \mathrm{mM}$ throughout the incubation. Cells were preincubated and assayed under isotonic (Control) or hypertonic (Mannitol) conditions. $\mathrm{Na} / \mathrm{H}$ antiporter activity is plotted. [Cycloheximide] $=0, n=8 ;$ [cycloheximide] $=100 \mathrm{mM}$, $n=9$. $* P<0.05$ versus control; $* * P<0.001$ versus control.

Increases in extracellular fluid osmolality acutely increase the activity of NHE1 and NHE2 expressed in antiporter-deficient Chinese hamster ovary cells (23). In the case of NHE1, hypertonicity-induced increases in $\mathrm{Na} / \mathrm{H}$ antiporter activity are not associated with changes in NHE1 phosphorylation (25). NHE4 expressed in antiporter-deficient cells demonstrates no $\mathrm{Na} / \mathrm{H}$ antiporter activity under isosmolar conditions, but is induced to express $\mathrm{Na} / \mathrm{H}$ antiporter activity by acute increases in osmolality (26). Thus, the activities of NHE1, NHE2, and NHE4 are increased acutely by hyperosmolality. This response provides a mechanism for increased $\mathrm{Na}$ uptake in cell volume defense during hyperosmolality.

By contrast, NHE3 expressed in antiporter-deficient cells is inhibited acutely by hypertonic cell shrinkage (23). In agreement with this, the $\mathrm{Na} / \mathrm{H}$ antiporter activities of rabbit proximal tubule suspensions, thick ascending limb, LLC-PK1 cells, and OK cells, cells which all express NHE3, are inhibited acutely by hyperosmolality $(21,22,27)$. In all of these studies, changes in extracellular fluid osmolality have been large, frequently around $200 \mathrm{mOsm} / \mathrm{liter}$. While these changes are physiologically relevant for the renal medulla, they are not physiologically relevant to cells in the renal cortex such as the proximal tubule. Nevertheless, in agreement with these results we found that hypertonicity acutely inhibits $\mathrm{Na} / \mathrm{H}$ antiporter activity in OKP cells.

Chronic increases in extracellular fluid osmolality of 200 $\mathrm{mOsm} / \mathrm{liter}$ for $72 \mathrm{~h}$ caused an increase in $\mathrm{Na} / \mathrm{H}$ antiporter activity in a mouse inner medullary collecting duct cell line (28). This was accompanied by an increase in NHE2 mRNA abundance and a decrease in NHE1 mRNA abundance. In vascular smooth muscle cells, chronic increases in extracellular fluid glucose concentration of $15 \mathrm{mM}$ caused an increase in $\mathrm{Na} / \mathrm{H}$ antiporter activity and NHE1 mRNA abundance (29). This effect, which was due to glucose per se rather than osmolarity, may contribute to vasoconstriction and hypertension in diabetics.

The mechanism by which hypertonicity is sensed and elicits changes in cell function have not been determined in mammalian cells. In yeast cells, a cascade has been defined wherein hy- perosmolality is sensed by transmembrane proteins ( $\operatorname{SinI}$ and ShoI), which activate parallel pathways leading to sequential activation of PbsII (a mitogen activated protein [MAP] kinase) and HogI (a MAP kinase) (30-32). Indeed, p38 and Jun $\mathrm{NH} 2$-terminal kinase (JNK), mammalian MAP kinases, are activated by hypertonicity and can complement mutations in HogI in yeast $(33,34)$. Activation of JNK by hypertonicity has recently been shown to be due to hypertonicity-induced clustering of receptors for epidermal growth factor, tumor necrosis factor, and interleukin-1, possibly triggered by perturbations of the cell surface (35).

\section{Acknowledgments}

We gratefully acknowledge the technical help of Martha Ferguson.

These studies were supported by grants DK-39298 and DK-48482 from the National Institutes of Health. P.M. Ambühl was supported by a grant from the Swiss National Foundation/Medizinisch-Biologische Stiftning.

\section{References}

1. Baum, M. 1987. Evidence that parallel $\mathrm{NaH}$ and $\mathrm{ClHCO}_{3}(\mathrm{OH})$ antiporters transport $\mathrm{NaCl}$ in the proximal tubule. Am. J. Physiol. 252:F338-F345.

2. Preisig, P.A., and F.C. Rector, Jr. 1988. Role of NaH antiport in rat proximal tubule $\mathrm{NaCl}$ absorption. Am. J. Physiol. 255:F461-F465.

3. Alpern, R.J., and F.C. Rector, Jr. 1996. Renal acidification mechanisms. In The Kidney. B.M. Brenner, editor. W.B. Saunders Co., Philadelphia. 408-471.

4. Sardet, C., A. Franchi, and J. Pouyssegur. 1989. Molecular cloning, primary structure, and expression of the human growth factoractivatable $\mathrm{Na} / \mathrm{H}$ antiporter. Cell. 56:271-280.

5. Orlowski, J., R.A. Kandasamy, and G.E. Shull. 1992. Molecular cloning of putative members of the $\mathrm{Na} / \mathrm{H}$ exchanger gene family. J. Biol. Chem. 267: 9331-9339.

6. Tse, C.M., S.R. Brant, M.S. Walker, J. Pouyssegur, and M. Donowitz. 1992. Cloning and sequencing of a rabbit cDNA encoding an intestinal and kidney specific Na/H exchanger isoform (NHE3). J. Biol. Chem. 267:9340-9346.

7. Collins, J.F., T. Honda, S. Knobel, N.M. Bulus, J. Conary, R. DuBois, and F.K. Ghishan. 1993. Molecular cloning, sequencing, tissue distribution, and functional expression of a $\mathrm{Na} / \mathrm{H}$ exchanger (NHE2). Proc. Natl. Acad. Sci. USA. 90:3938-3942.

8. Wang, Z., J. Orlowski, and G.E. Shull. 1993. Primary structure and functional expression of a novel gastrointestinal isoform of the rat $\mathrm{Na} / \mathrm{H}$ exchanger. J. Biol. Chem. 268:11925-11928.

9. Tse, C.M., S.A. Levine, C.H.C. Yun, M.H. Montrose, P.J. Little, J. Pouyssegur, and M. Donowitz. 1993. Cloning and expression of a rabbit cDNA encoding a serumactivated ethylisopropylamiloride resistant epithelial $\mathrm{Na} / \mathrm{H} \mathrm{ex}$ changer isoform (NHE2). J. Biol. Chem. 268:11917-11924.

10. Amemiya, M., J. Loffing, M. Lotscher, B. Kaissling, R.J. Alpern, and O.W. Moe. 1995. Expression of NHE3 in the apical membrane of rat renal proximal tubule and thick ascending limb. Kidney Int. 48:1206-1215.

11. Biemesderfer, D., J. Pizzonia, M. Exner, R. Reilly, P. Igarashi, and P.S Aronson. 1993. NHE3: a Na/H exchanger isoform of the renal brush border. Am. J. Physiol. 265:F736-F742.

12. Amemiya, M., Y. Yamaji, A. Cano, O.W. Moe, and R.J. Alpern. 1995. Acid incubation increases NHE3 mRNA abundance in OKP cells. Am. J. Physiol. 269:C126-C133.

13. Harris, R.C., B.M. Brenner, and J.L. Seifter. 1986. Sodium-hydrogen exchange and glucose transport in renal microvillus vesicles from rats with diabetes mellitus. J. Clin. Invest. 77:724-733.

14. Cole, J.A., L.R. Forte, W.J. Krause, and P.K. Thorne. 1989. Clonal sublines that are morphologically and functionally distinct from parental OK cells. Am. J. Physiol. 256:F672-F679.

15. Cano, A., P. Preisig, and R.J. Alpern. 1993. Cyclic adenosine monophosphate acutely inhibits and chronically stimulates $\mathrm{Na} / \mathrm{H}$ antiporter in OKP cells. J. Clin. Invest. 92:1632-1638.

16. Alpern, R.J. 1985. Mechanism of basolateral membrane $\mathrm{H} / \mathrm{OH} / \mathrm{HCO}_{3}$ transport in the rat proximal convoluted tubule. J. Gen. Physiol. 86:613-636.

17. Sargiacomo, M., M. Lisanti, L. Graeve, A. Le Bivic, and E. RodriguezBoulan. 1989. Integral and peripheral protein composition of the apical and basolateral membrane domains in MDCK cells. J. Membr. Biol. 107:277-286.

18. Le Bivic, A., F.X. Real, and E. Rodriguez-Boulan. 1989. Vectorial targeting of apical and basolateral plasma membrane proteins in a human adenocarcinoma epithelial cell line. Proc. Natl. Acad. Sci. USA. 86:9313-9317.

19. Gottardi, C.J., L.A. Dunbar, and M.J. Caplan. 1995. Biotinylation and 
assessment of membrane polarity: caveats and methodological concerns. Am. J. Physiol. 268:F285-F295.

20. Moe, O.W., R.T. Miller, S. Horie, A. Cano, P.A. Preisig, and R.J. Alpern. 1991. Differential regulation of $\mathrm{Na} / \mathrm{H}$ antiporter by acid in renal epithelial cells and fibroblasts. J. Clin. Invest. 88:1703-1708.

21. Soleimani, M., C. Bookstein, J.A. McAteer, Y.J. Hattabaugh, G.L. Bizal, M.W. Musch, M. Villereal, M.C. Rao, R.L. Howard, and E.B. Chang. 1994. Effect of high osmolality on $\mathrm{Na} / \mathrm{H}$ exchange in renal proximal tubule cells. $J$. Biol. Chem. 269:15613-15618.

22. Watts, B.A., III, and D.W. Good. 1994. Apical membrane Na/H exchange in rat medullary thick ascending limb: $\mathrm{pH}$ dependence and inhibition by osmolality. J. Biol. Chem. 269:20250-20255.

23. Kapus, A., S. Grinstein, S. Wasan, R. Kandasamy, and J. Orlowski. 1994. Functional characterization of three isoforms of the $\mathrm{Na}^{+} / \mathrm{H}^{+}$exchanger stably expressed in Chinese hamster ovary cells. J. Biol. Chem. 269:2354423552.

24. Baum, M., A. Cano, and R.J. Alpern. 1993. Glucocorticoids stimulate Na/H antiporter in OKP cells. Am. J. Physiol. 264:F1027-F1031.

25. Grinstein, S., M. Woodside, C. Sardet, J. Pouyssegur, and D. Rotin. 1992. Activation of the $\mathrm{Na}^{+} / \mathrm{H}^{+}$antiporter during cell volume regulation. $J$. Biol. Chem. 267:23823-23828.

26. Bookstein, C., M.W. Musch, A. DePaoli, Y. Xie, M. Villereal, M.C. Rao, and E.B. Chang. 1994. A unique sodiumhydrogen exchange isoform (NHE4) of the inner medulla of the rat kidney is induced by hyperosmolarity. $J$. Biol. Chem. 269:29704-29709.

27. Leviel, F., M. Froissart, H. Soualmia, J. Poggioli, M. Paillard, and M. Bichara. 1994. Control of $\mathrm{H}^{+} \mathrm{HCO}_{3}$ plasma membrane transporters by urea hy- perosmolality in rat medullary thick ascending limb. Am. J. Physiol. 266:C1157C1164.

28. Soleimani, M., G. Singh, G.L. Bizal, S.R. Gullans, and J.A. McAteer. 1994. $\mathrm{Na}^{+} / \mathrm{H}^{+}$exchanger isoforms NHE2 and NHE1 in inner medullary collecting duct cells. J. Biol. Chem. 269:27973-27978.

29. Williams, B., and R.L. Howard. 1994. Glucose induced changes in $\mathrm{Na}^{+} / \mathrm{H}^{+}$ antiport activity and gene expression in cultured vascular smooth muscle cells. Role of protein kinase C. J. Clin. Invest. 93:2623-2631.

30. Maeda, T., S.M. Wurgler-Murphy, and H. Saito. 1994. A two component system that regulates an osmosensing MAP kinase cascade in yeast. Nature. 369:242-245.

31. Brewster, J.L., T. de Valoir, N.D. Dwyer, E. Winter, and M.C. Gustin. 1993. An osmosensing signal transduction pathway in yeast. Science. 259:17601763.

32. Maeda, T., M. Takekawa, and H. Saito. 1995. Activation of yeast PBS2 MAPKK by MAPKKKs or by binding of an SH3 containing osmosensor. Science. 269:554-558.

33. Han, J., J.D. Lee, L. Bibbs, and R.J. Ulevitch. 1994. A MAP kinase targeted by endotoxin and hyperosmolarity in mammalian cells. Science. 265:808811.

34. Galcheva-Gargova, Z., B. Derijard, I.-H. Wu, and R.J. Davis. 1994. An osmosensing signal transduction pathway in mammalian cells. Science. 265: 806-808.

35. Rosette, C., and M. Karin. 1996. Ultraviolet light and osmotic stress: activation of the JNK cascade through multiple growth factor and cytokine receptors. Science. 274:1194-1197. 